\title{
Competencies of Nursing Interns at King Fahd Central Hospital
}

\author{
Al-Neami, Ibrahim ${ }^{1}$, Dimabayao, Cynthia G. ${ }^{2}$., Caculitan, Elizer R. ${ }^{3}$ \\ ${ }^{1}$ Director of Training and Scholarship Administration, M.O.H, GIZAN, Kingdom of Saudi Arabia \\ ${ }^{2}$ Asst.Professor, College of Nursing and Allied Health Sciences, Jazan University, K.S.A. \\ ${ }^{3}$ Asst. Professor, College of Applied Medical Sciences, Jazan University, K.S.A.
}

\begin{abstract}
This study aims to contribute in the molding of future competent nurses using the assessment result of their internship training so that strategies and proposals to develop them further could be made.

The descriptive method was used using all the 40 female nursing interns from Jazan University who were in their internship training at King Fahd Central Hospital during the School Year 2013-2014. A questionnaire based from the Ministry of Health Nursing Competency Program in the Kingdom of Saudi Arabia was used. Competencies were measured from the start and during their training. Data were treated through the weighted mean and t-test for dependent samples. Significant difference was tested at 0.05 alpha level.Results showed that the competencies of the nursing interns from the start was "Fair" (Wm=2.40). It improved to "Good" (Wm=3.04) during their training. Significant difference was seen mostly on Knowledge and Skills but not on Attitudes based on the comparison between the computed t-values and critical values on a 0.05 alpha level.Findings suggest that competencies of nursing interns are not yet well-developed as they start their training. Significant difference was attained during their training on knowledge and skills but not much on attitudes. Teamwork, collaboration with institutions offering nursing programs and revisiting the MOH Nursing Competency Program of the Kingdom of Saudi Arabia can bring out a better training and competency development among nursing aspirants.
\end{abstract}

Keywords: Attitudes, Knowledge, Nursing Competencies, Nursing Internship, Skills

\section{Introduction}

Nurses are very important in the in the health care profession. Their work is focused on the care of individuals, families and communities. Their approach to patient care, training and scope of practice is different from other health care providers. The end in view is to attain, maintain and recover optimal health, thus, attaining a quality life.

Competency connotes performance. Nursing competency describes skills, knowledge and other characteristics necessary in nursing professional practice. Competencies can be classified into behavioral and technical. Both of these are based on knowledge and may require professional judgment and clinical decision making. On one hand, technical competencies embrace administering and managing parenteral and enteral medication as well as calculating medication dosage. On the other hand, behavioral competencies include the articulation of nursing scope of practice to others, practicing ethical code for registered nurses, use evidences and critical inquiry to challenge, and support nursing practice. Moreover, these competencies are also practiced in collaboration with other health care providers to respond to rapidly changing complex health.

The US Institute of Medicine,[1] through their article on health professional education stressed the increased attention to factors that promote quality and safety of patient care. Since this mandate was issued, outcome of patient care have been increasingly important. Relatively, Cronevett, et al. [2] made a proposal that statement of the knowledge, skills and attitudes for each competency should be developed during the prelicensure nursing education. In this context, it is necessary that training of nursing be not only made intensive but assessment of their competencies be undertaken so that when they start to practice their career, they will be confident and live up to the expectations and demand of the profession.

The study by Almazwaghi [3] described the competencies needed by nursing intern students as identified by their preceptors and nurse educators who chose to work as nurses in intensive care units in Saudi Arabia. She identified nursing competencies in intensive care unit as development of needed skills competencies, knowledge application competencies and strategies for quality improvement. The study further revealed that there was agreement among participants that nursing intern students were not prepared to work in ICU immediately after their internship year. These interns may acquire satisfactory preparation during their internship through continuous evaluation, constant guidance, extended time period and orientation.

Den Uil-Westerlaken [4] looked into the competencies in nursing students for organized forms of clinical moral deliberation and decision making (MDD). Using 179 respondents, she found out that their scores in MDD knowledge and skills were significantly higher for students later in nursing education especially in the nursing process variable. As to attitudes towards MDD, scores were significantly higher after completing 
nursing training but lower scores appeared for MDD knowledge and skills particularly in relation to the organization. With these, she suggested that nursing education should reinforce students' attitudes to structural forms of MDD and clinical practice should reinforce nurses' MDD knowledge and skills. Moreover, both education should reinforce nurses' MDD competence in relation to the organization.

Dorgham [5] studied the relationship between nurse interns' satisfaction regarding internship program and clinical competence among 58 nursing interns at King Fahd University Hospital. She found out that that the highest mean score was noted for interpersonal and communication skills dimension followed by managerial dimension. Lowest mean scores were noted on knowledge and psychomotor skills dimension.

It is not only among nursing interns where competencies were studied but the professional nurses as well. One such study was made by Taechaveerakorn [6]. It was a study of clinical nurses' competencies based on career ladder in tertiary hospitals in Thailand. Experts from all fields and nursing organizations were asked to describe the core competencies of clinical nurses working in tertiary hospitals. After ranking the items they identified, they were able to come up with seven nursing competencies which are: Nursing care; selfdevelopment involving knowledge of nursing research and use of technology; leadership and management; human relationship and communication; decision making and problem solving; quality development and quality assurance; and nursing ethics.

Tzeng and Ketefian [7] also made an exploratory study on the demand for nursing competencies in Taiwan hospital system. A total of 89 nursing employers voluntarily participated. The skills presented to them were grouped into three factors as: basic-level patient care; immediate-level patient care and basic management; and advanced-level patient care and supervision. Their study confirmed that levels of nursing competencies needed differed by type of hospital accreditation. These levels also varied depending on types of services provided, employers, professional titles and tenure of currently employed nurses. The researchers also said that the questionnaire developed for this study could be used as one of the tools to communicate demand and supply of nursing competencies between nurse educators and employers. It could also be used to develop a checklist for evaluating adequacy of nursing programs in order to meet nurses' new role and responsibilities and improve nursing care quality in the fast-changing health care environment in Taiwan.

Looking into the competencies of nursing students taking their internship at King Fahd Central Hospital is important and timely in order to obtain a data-based feedback as to the extent the nursing school and training hospital have equipped them and developed further their nursing competencies so that they are very much ready to practice their profession. Hence, this study was conducted.

\section{Objectives}

This study aims to contribute to the development of future nurses and nursing profession considering the competencies of nursing interns developed before and acquired during their internship training. After a thorough analysis of their competencies, the ultimate aim of this study is to lay down strategies and proposals to improve the education and training of future nurses.

\section{Methodology}

The descriptive method was used using all the 40 female nursing students from Jazan University who are in their internship training at King Fahd Central Hospital during the School Year 2013-2014.

The instrument used to gather data was a questionnaire adopted from the dissertation of Nadia A. Aziz Fentianah [8]. However, only five competencies were adopted. These were on Emergency Response, Infection Control, Environmental Safety, Fall Prevention; and Hazardous Materials Safety. Medication Administration was not included. This tool was used because it was based from the Ministry of Health Nursing Competency Program in the Kingdom of Saudi Arabia. The questionnaire used a Likert's five-point scale such that 1=Poor; 2=Fair; 3=Good; 4=Very Good; and 5=Excellent.

The competencies of the nursing interns were measured twice. First was from the beginning of their training. Second was during their training which was taken after the seventh month.Data obtained were statistically treated through the weighted mean and t-test for dependent samples. Significant difference between the competencies developed before and acquired during their internship training was tested at 0.05 alpha level.

\section{Results}

The quantified results of the nursing competencies obtained from the respondents were placed in tabular forms to facilitate analysis and interpretation.

5.1 Emergency response. Accidents happen everyday and the victim is brought to the emergency room for treatment or life support. It can be a road traffic accident, domestic or caused by human, social or political conflicts. Sometimes, emergency cases also happen among inpatients. As Weiner [9] puts it, this makes the 
nurses to face the challenges of responding to natural, manmade and technological disasters. Table 1 shows the competencies of the nursing interns on emergency response.

Table 1 Competencies of the Nursing Interns onEmergency Response

\begin{tabular}{|c|c|c|c|c|c|c|c|}
\hline \multirow[b]{2}{*}{ No. } & \multirow[b]{2}{*}{ Competency Criteria } & \multicolumn{3}{|c|}{ Start of Training } & \multicolumn{3}{|c|}{ During Training } \\
\hline & & $\mathrm{Wm}$ & $\mathrm{R}$ & Int. & $\mathrm{Wm}$ & $\mathrm{R}$ & Int. \\
\hline & Knowledge : & & & & & & \\
\hline 1 & $\begin{array}{l}\text { States the nurses' responsibilities in emergency } \\
\text { situations. }\end{array}$ & 2.73 & 3 & Good & 3.25 & 2 & Good \\
\hline 2 & $\begin{array}{l}\text { States changes in basic life support (major and } \\
\text { minor changes). }\end{array}$ & 2.55 & 2 & Good & 3.30 & 3 & Good \\
\hline 3 & $\begin{array}{l}\text { Verbalizes clinical situations that require prompt } \\
\text { intervention. }\end{array}$ & 2.15 & 1 & Fair & 3.23 & 1 & Good \\
\hline & Mean & 2.48 & & Fair & 3.26 & & Good \\
\hline & Skills: & & & & & & \\
\hline 1 & $\begin{array}{l}\text { Achieves BLS provider status according to Saudi } \\
\text { Heart Association Standards. }\end{array}$ & 2.23 & 2 & Fair & 2.93 & 3 & Good \\
\hline 2 & Demonstrates utilization of emergency call system. & 2.25 & 3 & Fair & 2.83 & 2 & Good \\
\hline 3 & Demonstrates defibrillator and crash trolley checks. & 2.05 & 1 & Fair & 2.70 & 1 & Good \\
\hline & Mean & 2.18 & & Fair & 2.82 & & Good \\
\hline & Attitudes: & & & & & & \\
\hline 1 & $\begin{array}{l}\text { Respects for patients' life, dignity, rights and } \\
\text { safety. }\end{array}$ & 3.8 & 2 & $\begin{array}{l}\text { Very } \\
\text { Good }\end{array}$ & 4.55 & 2 & Excellent \\
\hline 2 & Takes initiative for professional actions. & 2.63 & 1 & Good & 3.53 & 1 & $\begin{array}{l}\text { Very } \\
\text { Good }\end{array}$ \\
\hline & Mean & 3.22 & & Good & 4.04 & & ry Good \\
\hline & Overall Mean & 2.63 & & Good & 3.37 & & Good \\
\hline
\end{tabular}

It can be seen that from the beginning of their training, the nursing interns had fair competencies on Knowledge $(\mathrm{Wm}=2.48)$. Specifically, however, they believed they were good in stating the nurse's responsibilities in emergency situations $(\mathrm{Wm}=2.73$ and in stating changing changes in basic life support $(\mathrm{Wm}=2.55)$. In Skills competencies, they manifested the three competency criteria fairly $(\mathrm{Wm}=2.18)$. They were found to have good Attitudes competencies $(\mathrm{Wm}=3.22)$. As a whole, the nursing interns had good competencies in Emergency Response ( $\mathrm{Wm}=2.63)$.

During their training, it could be notice that there was an increase of the numerical values in all the competency criteria, all of which were interpreted as "good". One competency criteria was noted where they were Excellent and this was in attitudes particularly of respect for patients' life, dignity, rights and safety (Wm=4.55). An overall mean of 3.37 was obtained.

5.2 Infection control. The basic principle of infection prevention and control is hygiene [10]. It is a very important component in the delivery of any health care. Infection control and measures are many and that the simplest is handwashing before and after any procedure. The most sophisticated one can be a high-level disinfection of surgical instrument. Implementing these measures can prevent transmission of diseases in the health care setting and in the community [11]. Table 2 shows the competencies of the respondents in their competencies on infection control.

From the start of the training of these nursing inters, they manifested generally good competencies in Knowledge $(\mathrm{Wm}=2.62)$. There were two competency criteria where they were found to "fair" competencies. These were in stating the types and indications for each isolation procedure $(\mathrm{Wm}=2.30)$ and on stating the guidelines in the prevention of infection related to intravascular device $(\mathrm{Wm}=2.48)$. Generally, they were found to have good competencies in Skills $(\mathrm{Wm}=3.01)$ the highest of which is on demonstrating hand washing technique $(\mathrm{Wm}=3.28)$. They also generally exhibited good competencies in attitudes $(\mathrm{Wm}=2.52)$, however, one competency criteria was found "Fair". This was on exhibiting appropriate level of concern to eliminate, prevent and control the occurrence of infection $(\mathrm{Wm}=2.45)$. As a whole, they showed good competencies on infection control $(\mathrm{Wm}=2.75)$ when they started their training.

During their training, their Knowledge competencies became better compared from the start. Although the interpretation is still "Good", yet the numerical value is higher $(\mathrm{Wm}=3.31)$. There were two competency criteria where they were found to have very good competencies. These were on discussing the measures to prevent needle sticks $(\mathrm{Wm}=3.50)$ and on stating the guidelines in the prevention of infection related to intravascular devices $(\mathrm{Wm}=3.50)$. Generally, they manifested the Skills competencies on a "Very Good" level $(\mathrm{Wm}=3.73)$. However, one among the competency criteria was found to have been performed by them on a "Good" level only. This was on maintaining asepsis before, during and after intravascular cannulation and other Invasive/non-invasive process $(\mathrm{Wm}=3.28)$. 
Table 2 Competencies of Nursing Interns onInfection Control

\begin{tabular}{|c|c|c|c|c|c|c|c|}
\hline \multirow[b]{2}{*}{ No. } & \multirow[b]{2}{*}{ Competency Criteria } & \multicolumn{3}{|c|}{ Start of Training } & \multicolumn{3}{|c|}{ During Training } \\
\hline & & $\mathrm{Wm}$ & $\mathrm{R}$ & Int. & $\mathrm{Wm}$ & $\mathrm{R}$ & Int. \\
\hline & Knowledge: & & & & & & \\
\hline 1 & States the guidelines of isolation procedure. & 2.50 & 3 & Good & 3.23 & 2 & Good \\
\hline 2 & $\begin{array}{l}\text { States the types and indications of each isolation } \\
\text { procedure. }\end{array}$ & 2.30 & 7 & Fair & 3.05 & 1 & Good \\
\hline 3 & Discusses the guidelines of Aseptic technique. & 2.80 & 6 & Good & 3.38 & 3 & Good \\
\hline 4 & Discusses measure to prevent needle sticks. & 2.88 & 5 & Good & 3.50 & 6.5 & $\begin{array}{l}\text { Very } \\
\text { Good }\end{array}$ \\
\hline 5 & States the procedure to report needle sticks. & 2.65 & 4 & Good & 3.25 & 4.5 & Good \\
\hline 6 & $\begin{array}{l}\text { Discusses guidelines in the prevention of surgical } \\
\text { wound infection and other nosocomial infections. }\end{array}$ & 2.75 & 3 & Good & 3.25 & 4.5 & Good \\
\hline 7 & $\begin{array}{l}\text { Discusses the guidelines in the prevention of } \\
\text { infection related to intravascular devices. }\end{array}$ & 2.48 & 2 & Fair & 3.50 & 6.5 & $\begin{array}{l}\text { Very } \\
\text { Good }\end{array}$ \\
\hline & Mean & 2.62 & \multicolumn{2}{|c|}{ Good } & 3.31 & \multicolumn{2}{|c|}{ Good } \\
\hline & Skills: & & & & & & \\
\hline 1 & Utilizes standard precautions. & 2.80 & 1 & Good & 3.58 & 2.5 & $\begin{array}{l}\text { Very } \\
\text { Good }\end{array}$ \\
\hline 2 & Demonstrates correct hand washing technique. & 3.28 & 5 & Good & 3.95 & 5 & $\begin{array}{l}\text { Very } \\
\text { Good }\end{array}$ \\
\hline 3 & $\begin{array}{l}\text { Utilizes protective equipment as indicated for each } \\
\text { procedure. }\end{array}$ & 3.05 & 3 & Good & 3.58 & 2.5 & $\begin{array}{l}\text { Very } \\
\text { Good } \\
\end{array}$ \\
\hline 4 & Discards used needles and sharps safely. & 3.25 & 4 & Good & 3.93 & 4 & $\begin{array}{l}\text { Very } \\
\text { Good }\end{array}$ \\
\hline 5 & $\begin{array}{l}\text { Assists in maintaining aseptic technique } \\
\text { (pre/intra/post operative). }\end{array}$ & 3.30 & 6 & Good & 4.13 & 6 & $\begin{array}{l}\text { Very } \\
\text { Good }\end{array}$ \\
\hline \multirow[t]{3}{*}{6} & $\begin{array}{l}\text { Maintains asepsis before, during and after } \\
\text { intravascular cannulation and other invasive/non- } \\
\text { invasive process. }\end{array}$ & 2.93 & 2 & Good & 3.28 & 1 & Good \\
\hline & Mean & 3.01 & \multicolumn{2}{|c|}{ Good } & 3.73 & \multicolumn{2}{|c|}{ Very Good } \\
\hline & Attitudes: & & & & & & \\
\hline 1 & Accepts patient with infectious disease. & 2.58 & 2 & Good & 3.10 & 1 & Good \\
\hline \multirow[t]{3}{*}{2} & $\begin{array}{l}\text { Exhibit appropriate level of concept to eliminate, } \\
\text { prevent and control the occurrence of infection. }\end{array}$ & 2.45 & 1 & Fair & 3.13 & 2 & Good \\
\hline & Mean & 2.52 & \multicolumn{2}{|c|}{ Good } & 3.12 & \multicolumn{2}{|c|}{ Good } \\
\hline & Overall Mean & 2.75 & \multicolumn{2}{|c|}{ Good } & 3.39 & \multicolumn{2}{|c|}{ Good } \\
\hline
\end{tabular}

In terms of Attitudes, the nursing interns showed a good performance on this $(\mathrm{Wm}=3.12)$. As a whole, a weighted mean value of 3.39 shows that the nursing interns have good competencies on infection control during their training.

5.3 Environmental safety. Accidents are difficult to predict. It can happen any time and in any place. In any workplace, be it in a school, a construction site and even in the hospital, it is always a concern to prevent incidents or accidents that might result to abnormal conditions and malfunctions of facilities, apparatuses or tools. The reduction or avoidance of adverse effects that result from such incidents or accidents is an important thing to consider. Therefore, knowing the proper way of operating facilities and apparatuses and managing incidents or accidents assures environmental safety. Table 3 shows the competencies of the nursing interns on environmental safety.

From the start of training, the nursing interns had all "Fair" competencies on environmental safety. This is evidenced by a weighted mean value of 2.05 for Knowledge; 2.24 for Skills; and 2.34 for Attitudes. The overall mean obtained was 2.21 .

Although the competencies were all performed on a "Fair" level, specifically, there were those which were better compared with the others. On knowledge, discussing the nurses' role in maintaining safe environment for patient, visitors and staff had the highest weighted mean value $(\mathrm{Wm}=2.43)$ while the lowest was on stating actions to take for a patient with latex allergy $(\mathrm{Wm}=1.70)$. On Skills, their highest was on demonstration safe use of hospital equipment $(\mathrm{Wm}=2.38)$ and their lowest was on inspecting electric equipment for signs of wear $(\mathrm{Wm}=2.05)$. On Attitudes, respecting life, human being and society and being positive towards environmental safety and health promotion was higher $(\mathrm{Wm}=2.35)$ than the competency criterion on exhibiting appropriate level of concern to eliminate, prevent and control environmental hazards $(\mathrm{Wm}=2.33)$.

During their training, some of the competencies have improved. In Knowledge, three of the competency criteria for environmental safety were manifested by them as "Good". These were on discussing the nurses' role in maintaining safe environment for patients, visitors and staff $(\mathrm{Wm}=2.93)$; lists common electrical and radiation hazards $(\mathrm{Wm}=2.78)$ and lists precautions for preventing electric shocks $(\mathrm{Wm}=2.65)$. Although the four competency criteria were still "Fair", yet the weighted mean values became higher. There were also two 
competency criteria in Skills where they became good during their training compared to the same competency from the start of training. These were on demonstrating safe electrical practice in hospital for patients, self and others $(\mathrm{Wm}=2.83)$; and demonstrating safe use of hospital equipment $(\mathrm{Wm}=2.90)$. Two of the competency criteria were still manifested by them as "Fair". In Attitudes, both of the competency criteria were manifested by them on a "Good" level. An overall mean of 2.83 shows that the nursing interns have good competencies on environmental safety during their training.

5.4 Hazardous materials safety. Hazardous material is a substance or material which could possibly give adverse effect on the safety of the public, handlers or carriers [12]. Hazardous materials in various forms can cause death, serious injury, long-lasting health effects and damage to buildings, home and other properties (en.wikipedia.org). Table 4 shows the competencies of the nursing students on hazardous material safety.

Table 3 Competencies of Nursing Interns onEnvironmental Safety

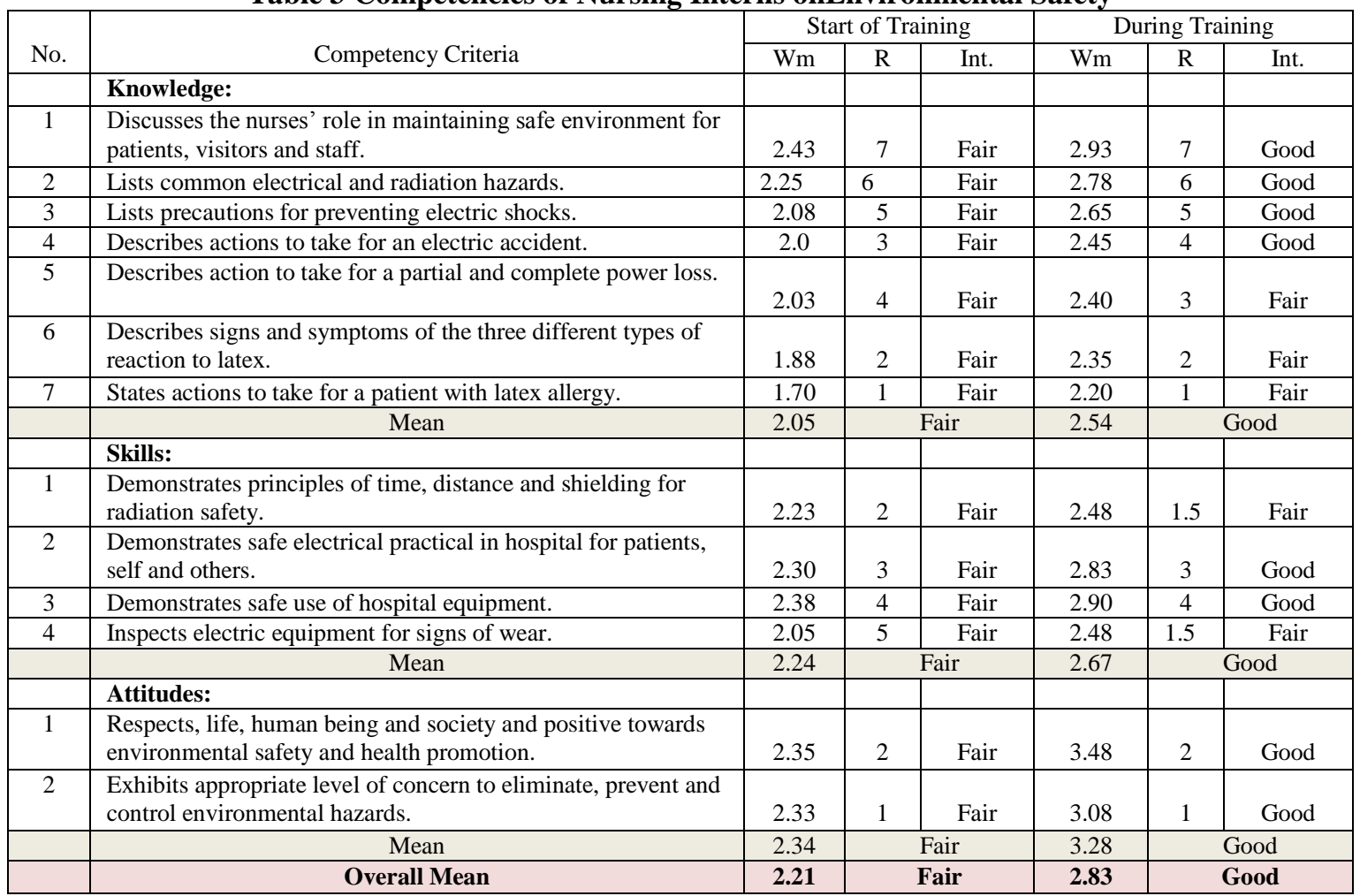

It can be noted from the table that from the start of the nursing interns' training, their competencies in hazardous materials under Knowledge $(\mathrm{Wm}=2.05)$ andSkills $(\mathrm{Wm}=1.98)$ were both "Fair". Specifically under Knowledge, the highest weighted mean value was shows that the nursing interns can state the nurse's responsibilities regarding hazardous materials $(\mathrm{Wm}=2.28)$. The lowest was on stating the role of other personnel regarding hazardous materials $(\mathrm{Wm}=1.85$. under Skills, the highest weighted mean value was put on safely storing hazardous materials $(\mathrm{Wm}=2.15)$. In Attitudes, one was "Good" and this was on respecting life, human being, and society and positive towards environmental safety and health promotions $(\mathrm{Wm}=3.08)$. The other criterion which is exhibiting appropriate level of concern to handle hazardous materials safely and appropriately was found "Fair" $(\mathrm{Wm}=2.40)$. The overall mean value of 2.26 shows that their competencies on Attitudes regarding hazardous materials are "Fair".

Table 4 Competencies of Nursing Interns onHazardous Materials Safety

\begin{tabular}{|c|l|c|c|c|c|c|c|}
\hline \multirow{2}{*}{ No. } & \multicolumn{1}{|c|}{ Competency Criteria } & \multicolumn{3}{|c|}{ Start of Training } & \multicolumn{3}{c|}{ During Training } \\
\hline & Knowledge: & & & & & & \\
\hline 1 & $\begin{array}{l}\text { Describes the meaning of the colors and numbers used } \\
\text { to identify chemicals/materials. }\end{array}$ & 2.03 & 2 & Fair & 2.63 & 3 & Good \\
\hline 2 & $\begin{array}{l}\text { States the nurse's responsibilities regarding hazardous } \\
\text { materials. }\end{array}$ & 2.28 & 3 & Fair & 2.35 & 2 & Fair \\
\hline 3 & $\begin{array}{l}\text { States the role of other personnel regarding hazardous } \\
\text { materials. }\end{array}$ & 1.85 & 1 & Fair & 2.23 & 1 & Fair \\
\hline & \multicolumn{1}{|c|}{ Mean } & 2.05 & \multicolumn{2}{|c|}{ Fair } & 2.40 & \multicolumn{2}{|c|}{ Fair } \\
\hline & Skills: & & & & & \multicolumn{2}{|c|}{} \\
\hline
\end{tabular}


Competencies of Nursing Interns at King Fahd Central Hospital

\begin{tabular}{|c|l|c|c|c|c|c|c|}
\hline 1 & Identifies hazardous materials. & 1.95 & 3.5 & Fair & 2.48 & 6.5 & Fair \\
\hline 2 & $\begin{array}{l}\text { Locates Chemical Hazard Bulletins (CHB) and/or the } \\
\text { manufacturer's Material Safety Data Sheet (MSDS). }\end{array}$ & 1.75 & 1 & Fair & 2.05 & 1 & Fair \\
\hline 3 & Demonstrates appropriate use of hazardous materials. & 1.85 & 2 & Fair & 2.13 & 2 & Fair \\
\hline 4 & Safely handles hazardous materials. & 1.95 & 3.5 & Fair & 2.30 & 3 & Fair \\
\hline 5 & Safely stores hazardous materials. & 2.15 & 7 & Fair & 2.35 & 4 & Fair \\
\hline 6 & Safely disposes hazardous materials. & 2.05 & 5 & Fair & 2.45 & 5 & Fair \\
\hline 7 & $\begin{array}{l}\text { Safely contains spills andor leaks of hazardous } \\
\text { materials. }\end{array}$ & 2.13 & 6 & Fair & 2.48 & 6.5 & Fair \\
\hline & \multicolumn{1}{|l|}{ Mean } & 1.98 & & 2.32 & Fair & \\
\hline 1 & $\begin{array}{l}\text { Attitudes: } \\
\text { towards environmental safety and health promotion. }\end{array}$ & 3.08 & 2 & Good & 3.38 & 2 & Good \\
\hline 2 & $\begin{array}{l}\text { Exhibits appropriate level of concern to handle } \\
\text { hazardous materials safely and appropriately. }\end{array}$ & 2.40 & 1 & Fair & 2.85 & 1 & Good \\
\hline & $\quad$ Mean Overall Mean & 2.74 & Good & 3.12 & Good \\
\hline & $\quad$ Fair & $\mathbf{2 . 6 1}$ & Good \\
\hline
\end{tabular}

During their training, one competency criterion under Knowledge was "Good". This was on describing the colors and numbers used to identify chemicals/materials $(\mathrm{Wm}=2.63)$. The others in this group were fair. Under Skills, all the competency criteria were still on the "Fair" level. However, it could be noticed that that the numerical values are higher compared to their assessment from the start of training. The overall mean value for this competency group is 2.32. Obviously, under Attitudes, both of the competency criteria were good. Respecting life, human being, and society and positive towards environmental safety and health promotion received a weighted mean value of 3.38. Exhibiting appropriate level of concern to handle hazardous materials safely and appropriately had a weighted mean value of 2.85 . As a whole, the mean for this competency group is 3.12. The overall mean of 2.61 shows that the nursing interns had good manifestation on the competency criteria on hazardous materials.

5.5 Falls prevention. As individuals advance in age, physical changes and health conditions, and sometimes the medications to treat those conditions, make fall more like to happen. This is a leading cause of injury among older adults [13]. However, falls do not only happen in the home, it can happen also in the health care setting. Table 5 shows the competencies of the nursing interns on falls prevention.

Apparently, both Knowledge and Skills competency group were assessed as "Fair" from the start of their training. The mean obtained for their competencies under Knowledge is 2.11. The competency criteria with highest rating was on identifying unsafe situations in the assigned environment $(\mathrm{Wm}=2.30)$. The lowest rating was on determining the status of specific and life threatening problem $(\mathrm{Wm}=1.58)$. In Skills, the mean obtained was 2.30 which mean "Fair". The competency criteria where they were "Good" and had the highest rating was on demonstrating safety measures to prevent falls and other incidents $(\mathrm{Wm}=2.58)$. The lowest rating could be seen on filling up forms for incident report and post-fall evaluation $(\mathrm{Wm}=2.15)$. Under Attitudes, both competency criteria show that the nursing interns were good. Introducing self and explaining the procedure had a rating of 3.05. Exhibiting appropriate level of concern for fall prevention had a rating of 2.90.

During their training, all the competency groups were rated "Good". Under Knowledge, the nursing interns obtained highest rating on determining the status of specific and life threatening problem $(\mathrm{Wm}=2.93)$. Their lowest rating could be seen on identifying unsafe situations in the assigned environment $(\mathrm{Wm}=2.78)$. A mean of 2.86 for this competency group shows that the manner by which the nursing interns attended to them was good. Under Skills, their highest rating was on demonstrating safety measures to prevent falls and other incidents $(\mathrm{Wm}=3.15)$. The lowest was on filling up incident report and post-fall evaluation $(\mathrm{Wm}=2.50)$. A mean of 2.82 indicates that these competency criteria were performed by the nursing interns in a good way. Under Attitudes, both competency criteria received a "Good" assessment. Introducing self and explaining the procedure had a rating of 3.43. Exhibiting appropriate level of concern for fall prevention had a rating of 3.30. A mean of 3.37 shows that the nursing interns had good attitudes on fall prevention.

5.6 Summary of the ratings on the different nursing competencies. In order to have a holistic way of looking at the nursing competencies shown in the previous tables, a summary table is hereby presented.

From the start of their training, the nursing interns had the highest rating in performing the competencies on infection control $(\mathrm{Wm}=2.75)$. This was followed by emergency response $(\mathrm{Wm}=2.63)$; falls prevention $(\mathrm{Wm}=2.46)$;hazardous materials $(\mathrm{Wm}=2.26)$ and environmental safety $(\mathrm{Wm}=2.21)$ in that order. Competencies under infection control were the only competency group performed by the nursing interns in a good way from the start of their training. They were "Fair" in their performanceon the competencies for emergency response, environmental safety, hazardous materials and falls prevention. 


\section{Table 5 Competencies of Nursing Interns onFalls Prevention}

\begin{tabular}{|c|c|c|c|c|c|c|c|}
\hline \multirow[b]{2}{*}{ No. } & \multirow[b]{2}{*}{ Competency Criteria } & \multicolumn{3}{|c|}{ Start of Training } & \multicolumn{3}{|c|}{ During Training } \\
\hline & & $\mathrm{Wm}$ & $\mathrm{R}$ & Int. & $\mathrm{Wm}$ & $\mathrm{R}$ & Int. \\
\hline & Knowledge: & & & & & & \\
\hline 1 & $\begin{array}{l}\text { Discusses safety precautions for promoting and } \\
\text { maintaining wellness of the clients. }\end{array}$ & 2.28 & 2.5 & Fair & 2.88 & 3 & Good \\
\hline 2 & Identifies unsafe situations in the assigned environment. & 2.30 & 4 & Fair & 2.78 & 1 & Good \\
\hline 3 & $\begin{array}{l}\text { Determines the status of specific and life threatening } \\
\text { problem. }\end{array}$ & 1.58 & 1 & Fair & 2.93 & 4 & Good \\
\hline 4 & $\begin{array}{l}\text { Discusses the plan of action to be taken in the event of } \\
\text { falls. }\end{array}$ & 2.28 & 2.5 & Fair & 2.83 & 2 & Good \\
\hline & Mean & 2.11 & & air & 2.86 & & ood \\
\hline & Skills: & & & & & & \\
\hline 1 & $\begin{array}{l}\text { Assesses the environment and identifies risky areas that } \\
\text { may be a source of falls. }\end{array}$ & 2.25 & 4 & Fair & 2.98 & 5 & Good \\
\hline 2 & $\begin{array}{l}\text { Identifies cognitive or physical deficits of clients that } \\
\text { may increase the likelihood of potential falls. }\end{array}$ & 2.20 & 3 & Fair & 2.58 & 2 & Good \\
\hline 3 & $\begin{array}{l}\text { Demonstrates safety measures to prevent falls and other } \\
\text { accidents. }\end{array}$ & 2.58 & 6 & Good & 3.15 & 6 & Good \\
\hline 4 & $\begin{array}{l}\text { Demonstrates familiarity with the assigned working } \\
\text { environment. }\end{array}$ & 2.45 & 5 & Fair & 2.95 & 4 & Good \\
\hline 5 & $\begin{array}{l}\text { Provides nursing interventions appropriate to assess risk } \\
\text { to client's likelihood to fall. }\end{array}$ & 2.18 & 2 & Fair & 2.78 & 3 & Good \\
\hline 6 & Fill incident report and post-fall evaluation. & 2.15 & 1 & Fair & 2.50 & 1 & Good \\
\hline & Mean & 2.30 & & air & 2.82 & & ood \\
\hline & Attitudes: & & & & & & \\
\hline 1 & Introduces self and explains procedure. & 3.05 & 2 & Good & 3.43 & 2 & Good \\
\hline 2 & Exhibits appropriate level of concern for fall prevention. & 2.90 & & Good & 3.30 & 1 & Good \\
\hline & Mean & 2.98 & & od & 3.37 & & ood \\
\hline & Overall Mean & 2.46 & & air & 3.02 & Go & \\
\hline
\end{tabular}

The nursing interns were "Fair" in doing the competency groups in emergency response but they were good in Attitudes $(\mathrm{Wm}=3.22)$. They made a good manifestation on the competency groups for infection control, the highest rating of which could be noted for Skills $(\mathrm{Wm}=3.01)$. The assessment of their competencies on environmental safety was "Fair" and their highest rating was on Attitudes $(\mathrm{Wm}=2.34)$. Competencies under hazardous materials were performed by the nursing interns in a "Fair" level but they were found "Good" in Attitudes $(\mathrm{Wm}=2.74)$. They were also "Fair" in doing the competencies for falls prevention but they were "Good" in Attitudes (Wm=2.98).

During their training, the numerical values increased in all the group competencies. The highest rating can still be seen on infection control $(\mathrm{Wm}=3.39)$. This is followed by emergency response $(\mathrm{Wm}=3.37)$; falls prevention $(\mathrm{Wm}=3.02)$; environmental safety $(\mathrm{Wm}=2.83)$ and hazardous materials $(\mathrm{Wm}=2.61)$.

Specifically, they manifested "Very Good" attitudes in emergency response $(\mathrm{Wm}=4.04)$. They were also found "Very Good" in Skills for infection control. The competency group with highest rating on environmental safety is Attitudes $(\mathrm{Wm}=3.28)$. On hazardous materials was on Attitudes $(\mathrm{Wm}=3.12)$. On falls prevention, the highest rating can still be seen on Attitudes $(\mathrm{Wm}=3.37)$.

As a whole, the nursing interns had "Fair" (Wm=2.46) manifestations on the different competency groups from the start of their training. After seven months of internship training, they have improved to "Good" level $(\mathrm{Wm}=3.04)$.

Table 6 Summary of Competencies Manifested by theNursing Interns

\begin{tabular}{|c|c|c|c|c|c|c|c|}
\hline \multirow[b]{2}{*}{ No. } & \multirow[b]{2}{*}{ Competencies } & \multicolumn{3}{|c|}{ Start of Training } & \multicolumn{3}{|c|}{ During Training } \\
\hline & & $\mathrm{Wm}$ & $\mathrm{R}$ & Int. & $\mathrm{Wm}$ & $\mathrm{R}$ & Int. \\
\hline \multirow[t]{5}{*}{1} & Emergency Response: & & & & & & \\
\hline & A. Knowledge & 2.48 & & Fair & 3.26 & & Good \\
\hline & B. $\quad$ Skills & 2.18 & & Fair & 2.82 & & Good \\
\hline & C. Attitudes & 3.22 & & Good & 4.04 & & Very Good \\
\hline & Overall Mean & 2.63 & 4 & Fair & 3.37 & 4 & Good \\
\hline \multirow[t]{5}{*}{2} & Infection Control: & & & & & & \\
\hline & A. Knowledge & 2.62 & & Good & 3.31 & & Good \\
\hline & B. Skills & 3.01 & & Good & 3.73 & & Very Good \\
\hline & C. Attitudes & 2.52 & & Good & 3.12 & & Good \\
\hline & Overall Mean & 2.75 & 5 & Good & 3.39 & 5 & Good \\
\hline \multirow[t]{2}{*}{3} & Environmental Safety: & & & & & & \\
\hline & A. Knowledge: & 2.05 & & Fair & 2.54 & & Good \\
\hline
\end{tabular}




\begin{tabular}{|c|c|c|c|c|c|c|c|}
\hline & B. $\quad$ Skills & 2.24 & & Fair & 2.67 & & Good \\
\hline & C. Attitudes & 2.34 & & Fair & 3.28 & & Good \\
\hline & Overall Mean & 2.21 & 1 & Fair & 2.83 & 2 & Good \\
\hline \multirow[t]{5}{*}{4} & Hazardous Materials: & & & & & & \\
\hline & A. Knowledge & 2.05 & & Fair & 2.40 & & Fair \\
\hline & B. Skills & 1.98 & & Fair & 2.32 & & Fair \\
\hline & C. Attitudes & 2.74 & & Good & 3.12 & & Good \\
\hline & Overall Mean & 2.26 & 2 & Fair & 2.61 & 1 & Good \\
\hline \multirow[t]{6}{*}{5} & Falls Prevention: & & & & & & \\
\hline & A. Knowledge & 2.11 & & Fair & 2.86 & & Good \\
\hline & B. Skills & 2.30 & & Fair & 2.82 & & Good \\
\hline & C. Attitudes & 2.98 & & Good & 3.37 & & Good \\
\hline & Overall Mean & 2.46 & 3 & Fair & 3.02 & 3 & Good \\
\hline & GRAND MEAN & 2.46 & \multicolumn{2}{|c|}{ Fair } & 3.04 & \multicolumn{2}{|c|}{ Good } \\
\hline
\end{tabular}

5.7 Significant Difference between the Competencies of theNursing Interns from the Start and During their Training.It was also interesting to know the significant difference between the competencies of the nursing interns from the start and during their training. This is to determine whether or not the improvement or development of their competencies showed significant changes. Using t-test for dependent samples for every competency group, the data obtained are shown in Table 7.

Table 7 Difference between the Competencies of the Nursing Interns from the Start and During their Training

\begin{tabular}{|c|c|c|c|c|c|c|c|c|c|c|}
\hline \multirow[t]{2}{*}{ No. } & \multirow{2}{*}{$\begin{array}{l}\text { Competency } \\
\text { Group }\end{array}$} & \multicolumn{2}{|c|}{$\begin{array}{l}\text { Start of } \\
\text { Training }\end{array}$} & \multicolumn{2}{|c|}{$\begin{array}{l}\text { During } \\
\text { Training }\end{array}$} & \multirow[t]{2}{*}{$\mathrm{N}$} & \multirow[t]{2}{*}{ df } & \multirow[t]{2}{*}{ t-value } & \multirow{2}{*}{$\begin{array}{l}\text { Critical value } \\
\qquad(0.05)\end{array}$} & \multirow[t]{2}{*}{ Result } \\
\hline & & Mean & sd & Mean & sd & & & & & \\
\hline 1 & $\begin{array}{l}\text { Emergency } \\
\text { Response: }\end{array}$ & & & & & & & & & \\
\hline & Knowledge & 2.48 & 0.30 & 3.26 & 0.36 & 3 & 4 & -4.536 & 2.78 & Significant \\
\hline & Skills & 2.18 & 0.11 & 2.82 & 0.12 & 3 & 4 & -6.99 & 2.78 & Significant \\
\hline & Attitudes & 3.23 & 0.83 & 4.04 & 0.72 & 2 & 2 & -1.06 & 4.30 & Not Significant \\
\hline 2 & Infection Control & & & & & & & & & \\
\hline & Knowledge & 2.62 & 0.21 & 3.31 & 0.16 & 7 & 12 & -6.92 & 2.18 & Significant \\
\hline & Skills & 3.10 & 0.21 & 3.73 & 0.32 & 6 & 10 & -3.98 & 2.23 & Significant \\
\hline & Attitudes & 2.52 & 0.91 & 3.12 & 0.02 & 2 & 2 & -8.99 & 4.30 & Significant \\
\hline 3 & $\begin{array}{c}\text { Environmental } \\
\text { Safety }\end{array}$ & & & & & & & & & \\
\hline & Knowledge & 2.05 & 0.24 & 2.54 & 0.26 & 7 & 12 & -3.65 & 2.18 & Significant \\
\hline & Skills & 2.24 & 0.14 & 2.67 & 0.22 & 4 & 6 & -3.27 & 2.45 & Significant \\
\hline & Attitudes & 2.34 & 0.01 & 3.28 & 0.28 & 2 & 2 & -4.69 & 4.30 & Significant \\
\hline 4 & $\begin{array}{l}\text { Hazardous } \\
\text { Materials }\end{array}$ & & & & & & & & & \\
\hline & Knowledge & 2.05 & 0.23 & 2.40 & 0.21 & 3 & 4 & -2.03 & 2.78 & Not Significant \\
\hline & Skills & 1.98 & 0.15 & 2.32 & 0.17 & 7 & 12 & -4.03 & 2.18 & Significant \\
\hline & Attitudes & 2.74 & 0.48 & 3.12 & 0.37 & 2 & 2 & -0.87 & 4.30 & Not Significant \\
\hline 5 & Falls Prevention & & & & & & & & & \\
\hline & Knowledge & 2.11 & 0.35 & 2.86 & 0.06 & 4 & 6 & -4.15 & 2.45 & Significant \\
\hline & Skills & 2.30 & 0.17 & 2.83 & 0.25 & 6 & 10 & -4.20 & 2.23 & Significant \\
\hline & Attitudes & 2.98 & 0.11 & 3.37 & 0.09 & 2 & 2 & -3.93 & 4.30 & Not Significant \\
\hline
\end{tabular}

It can be noticed from the table that Attitudes under three competency groups had no significant difference between their competencies from start of training and during training. These can be seen in Emergency Response, Hazardous materials and Falls Prevention. This is evidenced by the fact that the t-value obtained was lower than the critical value based on a 0.05 alpha level. Another competency was found to have no significant difference. This was on Knowledge under Hazardous Materials.

The other competency groups showed a significant difference in the competencies manifested by the nursing interns from the start of their training and during their training. It is because the result of the t-test shows that the computed t-values are greater than their critical values based on a 0.05 alpha level.

\section{Discussion}

The findings are indicative of a low level of nursing competencies from the start. In emergency response, for example, the nursing interns had a "Fair" level of competencies. This could be attributed to the content of the nursing curriculum and how the content is delivered to the students. While it is true that language 
barrier is there as a stumbling block between the faculty and the students, yet development of skills and attitudes do not necessarily depend on language. Knowledge of the content is very important. As to how much is given and how they are given to students are matters to look into. In a survey made by Weiner, Irwin, Trangestein and Gordon [14] in the United States, they said that nursing students are not the only ones lacking in the mastery of emergency preparedness content. Their survey also revealed that there is a lack of emergency preparedness content in the curriculum with only 4-5 hours of disaster preparedness throughout the whole country during the Academic year 2000-2001 through 2002-2003. In the same study, 74\% of the respondents felt that faculty were not at all prepared or poorly prepared to teach disaster preparedness content.

Other competency groups found to show a "Fair" level of competencies among the nursing interns were on environmental safety, hazardous materials and falls prevention. It is necessary that everyone is safe in the health care setting. Nursing practice is not only focused on the care of the sick but also on the promotion of health and safety. Thus, further injury can be avoided. Since the competency groups adopted for this study was based from the MOH of the Kingdom of Saudi Arabia, it appears that many of the nursing competencies are not developed well among the nursing students before they go to their internship year.

It is very noticeable from the findings also that many of the nursing competencies were manifested by the students to a higher level during their training. This is attested by the significant difference which resulted in many of the competency groups. This implies that the support given to them by the staff of the hospital and that of the training center is effective. This finding is in agreement with the statement by Almazwaghi [15] that nursing students may acquire satisfactory preparation during their internship year through continuous evaluation, consistent guidance, extended time period and orientation.

Competencies in Attitudes did not mostly have significant have significant difference from the start and during their training. This implies that they have not improved or developed their attitudes significantly as required in those competency groups. This could be an influence of their length of time or period of exposure to certain condition relative to their training. As Cherry puts it [16], she said that attitudes form directly as a result of experience. They may emerge due to direct personal experience or they may result from observation". Since the assessment made to them was seven months from the time they started their training, they could have made some changes already. However, it is assumed that the time is not yet sufficient for they are not yet through with their training. This is attested by the findings of den Uil-Westerlaken [17] in her study that attitudes towards MDD score significantly higher after completing nursing training.

Attitude of a nurse is very important for it is rooted on caring. The American Association of Colleges of Nursing [18]have identified caring as a foundation value for nursing. Shultz [19] also described attempts in nursing education to guide progression from a personal identification as a caring person to a professional identity of caring.

\section{Conclusion}

From the above findings and discussion, the following conclusions are drawn.

1. Competencies of nursing interns are not yet well-developed as they start their training. Significant difference is attained during their training particularly on knowledge and skills but not much on attitudes.

2. The assistance and support of the hospital and the training center of the hospital contributed much to the development of competencies of the nursing interns.

3. Teamwork, collaboration with institutions offering nursing programs and revisiting the MOH Nursing Competency Program of the Kingdom of Saudi Arabia can bring out a better training and competency development among nursing aspirants.

\section{Proposed Training Program to Improve the Competencies of Nursing Interns}

A training program is hereby proposed as prompted by the findings of this study. It considers four topics which can be taken up in day.

A. Organizer/Convenor: Ibrahim Al-neami

Director, Training and Scholarship Administration

King Fahd Central Hospital

A. Venue:King Fahd Central Hospital

Abu Arish, Jazan, Kingdom of Saudi Arabia

B. Date:To be determined by management

C. Duration: One day

D. Participants:Preceptors, staff nurses available and

Faculty of the College of Nursing recommended

by the Dean or Program Coordinator 
Invitation of other participants may be made depending upon the decision of management.

E. Facilities Needed: Hall, data player, laptop, whiteboard markers

F. Budget:To be determined by the management

G.

Proposed Training Program To Improve Competencies Of Nursing Interns At King Fahd Central Hospital

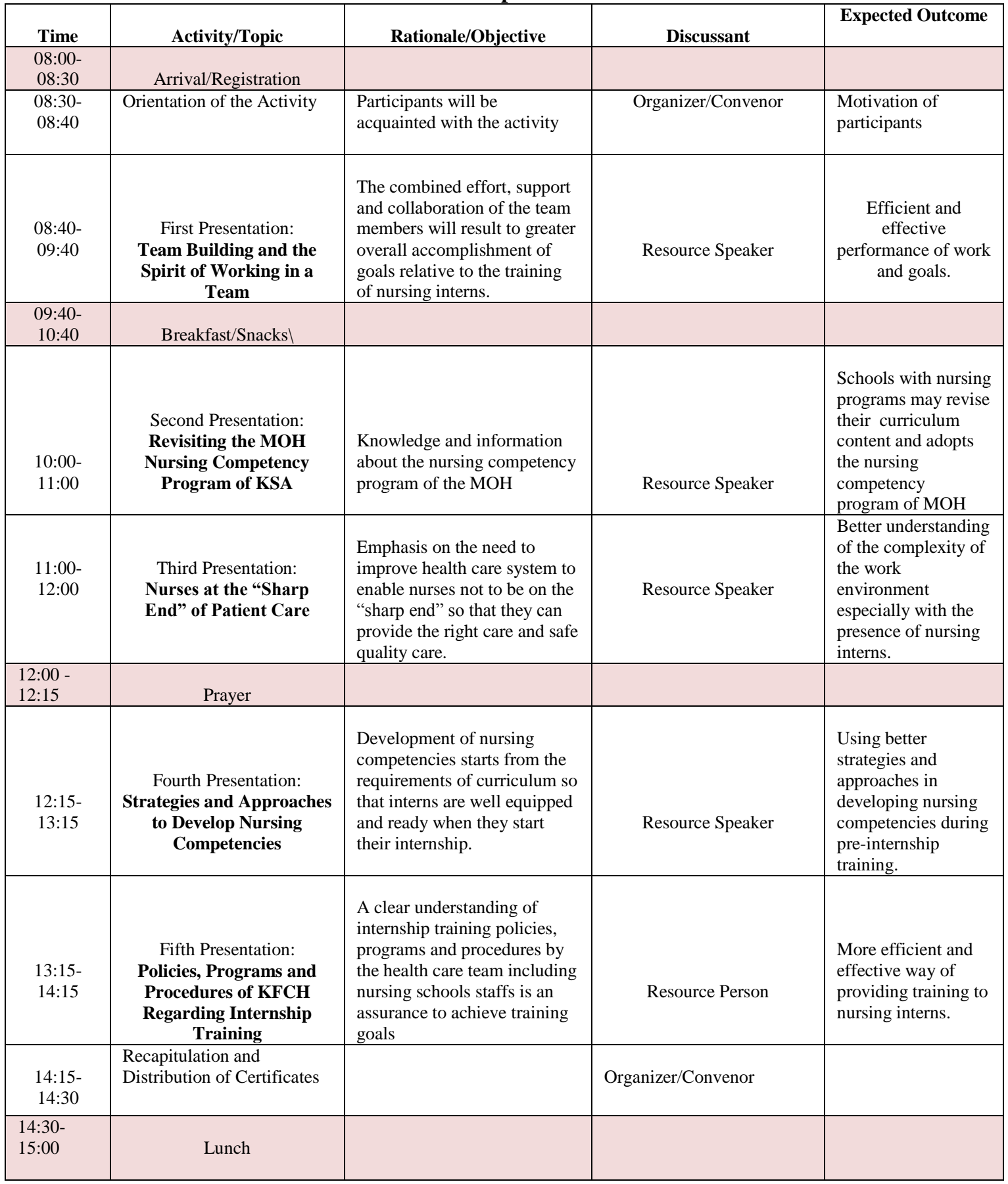

\section{Acknowledgements}

The preparation and completion of this research work was made possible through the guidance of Allah, the only God and the cooperation and support of friends in the Allied Health Professions. Hence, Ibrahim Al-neami Principal Researcher and Director of Training and Scholarship Administration is acknowledging their precious contributions sincerely. In particular, he is very thankful to the following: 
Cynthia G. Dimabayao and Elizer R. Caculitan Co-Researchers their patience and hardwork are beyond compare; Venus Albino her diligence in accomplishing assigned tasks regarding this work is very commendable; the NursingInterns fromJazan University Academic Year 2013-2014 for the cooperation given by providing the researcher with the much needed information; other staffs at King Fahd Central Hospital for extending their help in providing other things needed in the realization of the study. To them all, the researcher is giving his endless thanks.

\section{References}

[1]. Institute of Medicine.Health professional education, a bridge to quality. (Washington, D.C.: National Academic Press, 2003).

[2]. L Cronevett, G Sherwood, J Barnsteiner, J Disch, J Johnson, P Mitchell and J Warren, Quality and safety education for nurses. Nursing Outlook. 55, 122-131-16, 1016/j.outlook2007.02.006

[3]. S. Almazwaghi, Intensive care unit competencies of new nursing graduates in Saudi Arabia, nurse educator and preceptor perspectives. master's thesis, University of Saskatchewan, CA, 2013.http://hdl.handle.net/10388/RTD-2013-11-1925.

[4]. $\mathrm{J}$ den Uil-Westerlaken, Competencies in nursing students for organized forms of clinical moral deliberation and decision-making. Journal of Nursing Education and Practice, Vol. 3, No.11, 2013.www.sciedu.ca/jnep

[5]. S Dorgham, Relationship between nurse interns' satisfaction regarding internship program and clinical competence. The Medical Journal ofCairo University, 03/2013, 81(2). http://www.researchgate.net.

[6]. N Taechaveekorn, A study of clinical nurses' competencies based on career ladder, tertiary hospitals, The $17^{\text {th }}$ International Nursing research Congress Focusing on Evidenced-based Practice https://stti.confex.com/stti/congr06/technoprogram/paper 28257.htm.

[7]. H Tzeng and S Ketefian, Demandfor nursing competencies: an exploratory study in Taiwan's hospital system. Journal ofClinical Nursing, 2003, 12: 509-518.

[8]. N.A. Fentianah,Impact of nursing competence on quality of nursing care and safety of nursing practice. Doctoral diss, University of Phoenix, USA, 2012. gradworks.umi.com/3529356.pdf.

[9]. E Weiner, "Preparing nurses internationally for emergency planning and response". OJIN: The Online Journal of Issues in Nursing. Vol. 11, no. 3, manuscript 3. Doi: 10.3912/OJIN.Vol.11No.03.Man03

[10]. www.who.int/topic/infection_control.

[11]. www.health.ny.gov/.../diseases/reporting/communicable/infection.

[12]. www.ehs.neu.edu

[13]. www.mayoclinic.org/fall-prevention/ART_20047358.

[14]. E Weiner, M Irwin, P Trangestein and J Gordon, Emergency preparedness curriculum in US nursing schools, survey results. Nursing EducationPerspectives, 26 (6), 334-339.

[15]. SAlmazwaghi, Intensive care unit competencies of new nursing graduates in Saudi Arabia, nurse educator and preceptor perspectives. master's thesis, University of Saskatchewan, CA, 2013. http://hdl.handle.net10388RTD-2013-11-1925.

[16]. K Cherry, Attitudes: how attitudes form, change and shape own behavior. Psychology.about.com/od/socialpsychology/attitudes.

[17]. J den Uil-Westerlaken, Competencies in nursing students for organized forms of clinical moral deliberation and decision-making. Journal of Nursing Education and Practice, Vol. 3, No.11, 2013. www.sciedu.ca/jnep

[18]. American Association of Colleges of Nursing, The essentials of baccalaureate education for professional nursing practice. (Washington, D.C., USA, 1998).

[19]. CMShultz, Building a science of nursing education; foundation for evidence-based teaching-learning. New York: the national League of Nursing: 2009). 